\title{
The ratio of security and freedom of thought in the sphere of politics
}

\author{
HamedMolazem * \\ Department of Political Science, Islamic Azad University, Tabriz, Iran
}

\begin{abstract}
Security is a subject which is very vital and lack of it would be very dangerous.humans and all other creatures due to their instincts are always looking for security. However society would cease to make progress if any individual struggles to preserve security by themselves. Therefore forstabilizing security humans rely on a institute such as government so that they would be able to progress in a specific way in order to bloom economic thinking .yetsecurity in a society is different with environmental security.Environmental security which is built based on Ideology will cause to create a unipolar society.Fascismin Italy, Nazi in Germany (rightwing totalitarianism) and or Istalin's Communist soviet union(left-wing totalitarianism) are the examples.
\end{abstract}

Keywords:freedom, sphere of politics, environmental security.

\section{INTRODUCTION}

The main question is that does security have any contradiction with freedom?The hypothesis of necessary security is essential for freedom of thought however a secure society will cause restrictions on freedom of thought.Plato believed that war is a natural subject which is in the nature of every human being he also believed war is originated from sick society foundations .on the other hand in Machiavelli's opinion war originates from society's evolution and it is natural. Based on Islamic thought society which is built from humans with the same way of thinking and belief have accepted the same goal with political and martial organizations moreover unity is one of the elements which is inseparable. (Amid Zanjani, political jurisprudence 184). Creating a united nation does not mean a nation with a unique thought growth, having different thoughts and also harmony in order to preserve humans munificence is necessary for a society so that humans would ponder candidly .However, freedom of thoughts will be dramatically affected by securing a nation. as an example in medieval period human's beliefs were inspected ( history of civilization - Will Durant 1138 ) therefore it seems that war would break unity strategy and harmony of thought in a society moreover it would create a unipolar society which would put limitations on freedom of thoughts and speech in order to protect freedom of thought security is necessary although freedom has priority to security however Thomas Heirner believes security has priority to freedom also both of these philosophers belonged to society convection .Plato and Marx were pioneers of closed society and on the other hand Socrates and Aristotle were pioneers of open society.closed society has orientation toward totalitarianism and open society has orientation toward anarchy however there should be a balance between these two subjects and it is only achievable by cooperation of security forces .Checking security of Europe and middle east in Syrian war based on Nukanti's thought.Based on Nukanti's thought which is continuing Kant's path,moderation and separation has been considered at the same time. In this thought humans have been recognized however they are unable to achieve recognition. Aristotle believed Syrian war caused to create a kind of security in Europe and middle east also humans tryto protect their own security although there is no place of freedom of thought the countries which gain benefits in Syrian war have made closed and secure environment also ideology has become more important . by applying this method societies will have closed environment for thoughts and in results it will make the country weaker.In Aristotle's point of view there is a direct connection between secure environment and political freedom .

Freedom of thought and security environment in USA.

C. Wright Mills Believes those who dominate and penetrate in US army have achieved significant power and credit among their political and economic partners.some of professional armies have taken out themselves from military and stepped into another main areas in US society. In many of challenging issues and subjects military has been successful in achieving their goals or they would stop the decisions which are against their desire. (Power Elite 279 Mills) this means gaining power by securing a society.AlthoughUS is a free country however it is challenging their own citizens by creating enemies such as Muslims and terrorists. We can explain freedom in two aspects; positive freedom and negative freedom.negative freedom has no limitation while positive freedom is controlled in specific law frames .therefore freedom without control could lead to chaos and this 
requires secure environment for freedom of speech.Plato believed freedom must be controlled by individuals and move based on their own ideas, porch thinkers were considering freedom as moving inside a castle. Viko founder of cultural pluralism believed difference between natural and partial affairs is significantly important.

\section{CONCLUSION}

Political theory is planning and discussing in regards to secure freedom and development. Therefore this essayis referring that if international levers could be created and nations would be able to progress based on these levers, desirable freedom will be achievable .In inside war the purpose of strategy inBumer's point of view is to apply methods in order to make the enemies obedient from psychological aspect therefore using security based on psychology is more useful than security itself, moreover the environment for thoughts will be created.

\section{REFERENCES;}

[1] The political poverty,Abbasali amid zanjani, Amir kabir publications, 347,2004.

[2] History of civilization Will Durant scientific publishing, translated by Ziyaaldintabatabay,489,2001.

[3] Power elites, C wright mills, translated by cultural foundation research,2004.

[4] Hossein, reason in politic,453,2002. 